\title{
Guidance and Counseling Teacher's Role and Function within Disruption Era
}

\author{
Pepi Nuroniah \\ Educational Psychology and Guidance \\ Universitas Pendidikan Indonesia Bandung \\ pepinuroniah@upi.edu
}

\author{
Rina Nurhudi Ramdhani \\ Educational Psychology and Guidance \\ Universitas Pendidikan Indonesia Bandung \\ rinanurhudiramdhani@upi.edu
}

\author{
Nadia Aulia Nadhirah \\ Educational Psychology and Guidance \\ Universitas Pendidikan Indonesia Bandung \\ nadia.aulia.nadhirah@upi.edu
}

\begin{abstract}
This study aimed to describe the perception of the role and function of the guidance and counseling teacher within the era of rapid and precise disruption. The research was conducted with qualitative design with a phenomenological model. Research subjects were sociology education students from various regions and guidance and counseling teachers with four years of experience. Primary data obtained by in- depth interviews. Secondary data obtained through observation and field notes. The results of the study described that subjects have several perceptions of the role of guidance and counseling teacher's, such as irrelevancy, fierce, favoritism and lacking attention. Meanwhile the subject of the guidance and counselor teachers themselves have several perceptions, such as the lack of effectivity within the job. The role and function of the guidance and counseling teacher have not been optimized because of the lack of synergy perceptions between students and guidance and counseling teachers.
\end{abstract}

Keywords: disruption era, role and function, guidance and counseling teachers

\section{INTRODUCTION}

One of the elements of successful education process is the quality of the educator. Facilities, programs and curriculum are all important but educators and students are the main points in the course of the education process. The existence of guidance and counseling teachers or so-called counselors in the national education system is stated as one of the qualifications of educators, in line with the qualifications of teachers, lecturers, tutors, tutors, lecturers, facilitators, and instructors. Guidance and counseling teacher's are expected to perform provide guidance and counseling services that must always be driven by altruistic motives, empathic attitudes, respect for diversity, and prioritizing the counselee's interests, and always pay close attention to the long-term impact of the services provided. Guidance and counseling is an effort to optimize the potential of students towards independence, especially in the era of distrust.

The disruptive era demands everyone to be fast, precise, and innovative. This is an opportunity as well as a challenge faced by guidance and counseling teachers. Other regulations that strengthen the counselor's position are the Kurikulum 2013 in the Peraturan Pemerintah Tahun 2014 No. 111 that clearly stated the duties and functions of guidance and counseling teachers. The demands in various eras and as time goes on, changes are required. This is similar with the objectives of the Kurikulum 2013 that aimed to prepare Indonesian to have the ability to live as individuals and citizens who are productive, creative, innovative, and affective and able to contribute to the life of society, nation, state and world civilization.

Guidance and counseling was once seen as a solution to solve problems, but slowly transforms as a platform to explore the potential development of students. It was no longer measuring behavior change with punishment and reward as explained by behavioristic theory. According to Kasali conventional teaching, rigid, and less competitive are not stimulating the power of innovation, as the students are shackled in rigid rules. In line with Triyono who explained the orientation of guidance and counseling in the era of disruption is not only to solve problems but to identify students' potentials and facilitating their development according to the nature of each student. According to the post modern approach, guidance and counseling teachers are supposedly focus on solutions and empower competencies, skills and qualities that can be used by students.

Without any innovation and lack of competencies' improvement, the role and function of guidance and counseling teachers can easily be disrupted with information technology (IT) because students are able to find information in the personal, social, academic and career fields through social media. As students belonged to the Generation Z, technology in the era of disruption making them unique. Generation $\mathrm{Z}$ found that accessible and interactive communication are essential in establishing relationships with others. Students might realize that they need guidance and counseling services, but the role of guidance and counseling teachers seen as 
irrelevant. Generation $\mathrm{Z}$ is also called as do-it-yourself generation since they are able to complete their tasks on their own because they can learn through YouTube independently.

Based on the explanation above, the researcher aimed to find out the perceptions of students and guidance and counseling teacher's experience regarding to the perception of the role and function of guidance and counseling teachers in the era of disruption.

\section{RESEARCH METHOD}

\section{a. Research Design}

The research used qualitative research method with phenomenological model. The use of phenomenological models is intended to reveal the meaning of each phenomenon that occurs around the guidance and counseling teacher. Phenomenological model is a model or approach in qualitative research that explores in detail a person's personal life experience with the results of a description of how an individual gives meaning to phenomena related to the personal world and its solutions [9].

Based on the explanation above, the researcher tried to find the participant's perspective on the phenomena that occur to them using the phonomenology model. The intended perspective meant the role and function of the guidanec and counseling for both students and guidance and counseling teachers.

\section{b. Research Subject}

The selection of research subjects is done through an approach to groups that met the required characteristics in accordance with the research topic and personal contacts. The accurate selection of subjects needs to meet the characteristics and experience requirements that are appropriate to the phenomenon under study. The subjects were Educational Sociology FPIPS UPI students.

\section{c. Data Collection Methods}

\section{Interview}

Data obtained through in-depth interviews. Through this type of interview, researchers tried to reduce statements made by research participants about a topic to the main propositions or stand out as research [9]. The depth of data experience that was revealed depended on many things, such as the researcher's expertise, familiarity, opennes between the researcher and the subject, and focus on the focus of the study [10]

\section{Observation}

Observations are the process of making intuitive conclusions by researchers during and after making observations of the reactions that appear to the participants when interacting with certain topics or phenomena [9]. When conducting this observation, the researcher records with both structured and semistructured way. One of the example is by asking a number of questions that researchers really want to know.

\section{d. Data Analysis Technique}

The data analysis technique used in this research was the phenomenological analysis technique. Significant statements can be found in words, sentences, or several sentences in order to obtain a special meaning about a phenomenon. Significant statements can be found in words, sentences, or phenomenon [9].

\section{e. Validation Method}

Determination of validity is done through a participant check or check the participant members. Based on this, the method used is descriptive validity method. The descriptive validity in question refers to the factual accuracy of the phenomena described by qualitative researchers [9]. In an effort to obtain descriptive validity, the method that can be used is through triangulation of researchers related to data collection, data analysis, and data interpretation. Operationally, triangulation is a process of crosschecking informations and conclusions through a variety of procedures or sources. If various sources or procedures are consistent, the researcher is considered to have obtained valid data or conclusions.

\section{a. Students' Perspective}

\section{RESULT}

Effective guidance and counseling services are programme that are considered beneficial by students. Suherman explained that guidance and counseling services at school should have a positive impact on students, parents, subject teachers, homeroom teachers, school leaders, school committees and even counselors or guidance and counseling teachers. Based on the interviews conducted by the researchers, questions about guidance and counseling services in schools through the experience of 49 sociology education students in UPI from various regions describing these statements: BK teachers were fierce, less active, were not counseling education graduates, did not provide relevant solutions, always blamed students, lacking insight, irrelevant, taking sides, not present as much as they needed, and lastly, the guidance and counseling room is considered as an uncomfortable place. $80 \%$ of participants expressed negative experiences that they felt about guidance and counseling teachers and 20\% of participants experienced unpleasant experiences.

The sentence which implies the above explanation is said by DFS that guidance and counseling teachers are "demanding respect, promising to give rewards but not implemented, a little boring, having dull personalities, and are strict about rules". Similar statement by WFG said that "guidance and counseling teachers are not attentive and just stayed in their respective room, trying to convince them to not switch major, and lacking of updates". Based on participant statements, participants did not get the benefits of guidance and counseling services as they should have obtained in accordance with Suherman's explanation, including providing strategies to overcome low achievement, increasing agreement to 
determine learning strategies, helping to increase student support.

However, opposite statement expressed by IT "guidance and counseling teachers motivates and helps the students with all of their efforts so that the students can succeed. One of the examples are their successful college admission". The phrase is in accordance with the statement of Suherman regarding the benefits of guidance and counseling services including ensuring the right path to obtain further educational opportunities and helping students to increase success.

Expressions of feelings and experiences by participants are described partially. The average statement of student experience from 49 schools in West Java, Banten and Jakarta stated that they do not feel the role and function of guidance and counseling teachers. They hope that guidance and counseling teachers actively pay attention, accept students as they are, have an active role, have extensive knowledge, do not underestimate or do not stereotype. Feelings and experiences felt concluded there was a misunderstanding of the role and function of the guidance and counseling due to the personal side of the counselor themselves.

\section{b. Guidance and Counseling Teachers' Perspectives}

Based on interviews with a guidance and counselor teacher who have been involved in education for 32 years, believed that every formal or non-formal education setting have actually tried to create an ideal education and constructive services for students. Problems faced by (1) parents who lack trust in educational institutions (2) students who lack trust in guidance and counseling teachers (3) Busy guidance and counseling teachers (4) lack of financial support from schools and (5) use of information technology.

Parents who lack trust in educational institutions are seen in the process of solving students' problems. The process of solving students' problems needs parental involvement. Parental involvement is expected to be able to support students for more positive behavior changes with a short period of time. The fact is that in the field parents sometimes do not accept the behavior of students who are considered by parents not to behave like their children at home. This can be seen from the many statements of parents who say "my child in the house is a good child, always obeying the parents' orders, so it is impossible to break the rules". The rejection of the fact becomes an obstacle for guidance and counseling teachers to work with parents who sometimes defend the students. So that guidance and counseling teachers who should have a repair function become ineffective in the implementation process.

Students who lack trust in their guidance and counseling teachers impacting the guidance and counseling services. Students might feel that it is not important to seek help from guidance and counseling teachers. Guidance and counseling teachers are supposedly help students to have an understanding of themselves and their environment as a safety function and guidance and counseling teachers who strive to always overcome various problems that may occur and try to prevent it, though this preventing function guidance and counseling teachers to provide guidance.

The Guidance and Counseling teacher's busy schedule or their lack of presence happened because of the imbalance number of students with the number of guidance and counseling teachers. For example, there are 900 students with three guidance and counseling teachers, which means one guidance and counseling teacher is responsible for 300 students. This is not in accordance with minister's regulation in Peraturan Menteri Tahun 2014 No 111 who stated that one teacher must be responsible to 150 students, maximum.

The comfort zone felt by the guidance and counseling teachers because of their hectic schecules and their burden that they have little opportunity to develop themselves. Not all guidance and counseling teachers are able to joing the meeting with MGBK and ABKIN if the activities were not held during holidays and if they had lack of support from the school in terms of financial and time. However, these statements are not yet supported by accurate data in the field.

The seminars and developmental program that were joined by guidance and counseling teachers were still in the realm of knowledge rather than direct methods or applications that could be used in the field. So that technological advancements in the era of disruption have not been able to bring a rapid pace in the development of guidance and counseling because the problems faced by guidance and counseling teachers are still the same problem of existence in running their roles and functions in displaying guidance and counseling services.

In this disruptive era the use of technological devices require guidance and counseling teachers to have some initiatives to learn and keep up with the times. The development of students is inseparable from the influence of the environment in physical, psychological and social aspects. Guidance and counseling teachers are required to be able to use laptops / computers, androids, and other technological devices. As a guidance counseling teacher who is considered to be a senior and has limitations in the learning process, it requires considerable study time to learn the technology in order to adapt to the environment. In line with Surya who described global development with all its characteristics directly or indirectly is a challenge as well as an opportunity for the guidance and counseling profession [14]. The guidance and counseling profession is expected to be able to proactively respond to challenges about opportunities through professional services so that they are able to assist individuals in adapting to global demands.

\section{CONCLUSION}

The role and function of guidance and counseling teachers according to the perspective of the students: fierce, less active, non- counseling graduates, do not provide solutions, often blaming students, lack of insight, irrelevant, rarely present, and the space that 
the guidance and counseling teachers use are usually uncomfortable.

The role and function of guidance and counseling teachers according to the perspective of the guidance and counseling teachers who still seen as less important figure in schools because (1) parents who lack trust in educational institutions (2) students who lack trust in the teacher (3) guidance and counseling teachers hectic activities and (4) lack of financial support from the school.

\section{REFERENCES}

[1] Undang-undang Republik Indonesia Nomor 20 Tahun 2003 Tentang Sistem Pendidikan Nasional

[2] Peraturan Menteri Pendidikan Nasional Republik Indonesia Nomor 27 Tahun 2008 tentang Standar Kualifikasi Akademik dan Kompetensi Konselor.

[3] Peraturan Menteri Pendidikan Nasional Republik Indonesia Nomor 111 Tahun 2014 tentang Bimbingan dan Konseling

[4] Hanurawan, F. 2015. Perspektif Alternatif dalam Psikologi Pendidikan. Malang: UM Penerbit dan Percetakan

[5] Kasali, R.2019. Disruption Tidak Ada yang Tak Bisa Diubah Sebelum Dihadapi Motivasi Saja Tidak Cukup. Jakarta: Gramedia

[6] Triyono. 2018. Mereka-Reka Strategi Bimbingan Dan Konseling Dalam Era Disrupsi/Revolusi Industri distrupsi Bagi Generasi Z. Prosiding Seminar Nasional
Strategi Pelayanan Bimbingan dan Konseling di Era Disrupsi. Semarang: Pengurus Daerah ABKIN Provinsi Jawa Tengah

[7] Palmer, S. 2010. Konseling dan Psikoterapi. Yogyakarta: Pustaka Pelajar

[8] Stillman, D dan Stillman, J. 2018. Generasi Z Memahami Karakter Generasi Baru Yang Akan Mengubah Dunia Kerja. Jakarta: PT Gramedia Pustaka Utama

[9] Hanurawan, F. 2016. Metode Penelitian Kualitatif untuk Ilmu Psikologi. Jakarta: PT Raja Grafindo Persada

[10] Mappiare-AT, A. 2013. Tipe-tipe Metode Riset Kualitatif Untuk Eksplanasi Sosial Budaya dan Bimbingan Konseling. Malang: Elang Mas

[11] Creswell, J.W. 2012. Research Design Pendekatan Kualitatif, Kuantitatif, dan Mixed.Yogyakarta: Pustaka Pelajar

[12] Suherman, Uman. (2015). Manajemen Bimbingan dan Konsleing. Bandung: Rizqi Press.

[13] Yusuf Syamsu LN \& Nurihsan Juntika. (2011). Landasan Bimbingan dan Konseling. Bandung: PT Remaja Rosdakarya

[14] Surya, Muhammad. (2008). Mewujudkan bimbingan dan konseling professional. Bandung: Jurusan Psikologi Pendidikan dan Bimbingan FIP UPI. Tidak diperjual belikan. 